\title{
Long-term fertiliser application and fertility of hill soils
}

\author{
M.G. LAMBERT, A.D. MACKAY and D.A. COSTALL \\ AgResearch, Grasslands Research Centre, PB 11008, Palmerston North
}

\begin{abstract}
Application of phosphatic fertiliser to legume/grass pastures, and increased stocking rate, is commonly assumed to increase soil organic matter (estimated from soil carbon) content, to lower soil $\mathrm{pH}$, and to increase soil Olsen $\mathrm{P}$ status. Changes in these variables in soils derived from sedimentary parent material were monitored over 16 years, in a longterm grazing experiment on southern North Island hill country. There were 2 fertiliser treatments, principally high (capital applications followed by $375 \mathrm{~kg} / \mathrm{ha} /$ year) and low (125 kg/ha/year) superphosphate application. There was a net loss of soil C of approximately $200 \mathrm{~kg} / \mathrm{ha} /$ year in both treatments, although annual $\mathrm{C}$ inputs to the soil were greater (by $1000 \mathrm{~kg} / \mathrm{ha}$ ) in the high fertiliser soils. Soil $\mathrm{pH}$ increased slightly; and Olsen P status reflected $\mathrm{P}$ application, although it was less responsive to $\mathrm{P}$ application $(13 \mathrm{~kg} \mathrm{P} / \mathrm{ha}$ applied above maintenance for 1 Olsen $\mathrm{P}$ unit increase) than has commonly been assumed is the case (4-7 $\mathrm{kg} \mathrm{P} / \mathrm{ha}$ per unit). The most likely reason for net loss of soil $\mathrm{C}$ is increased decomposer activity in the soil, and the greater proportion of plant-fixed $\mathrm{C}$ ingested by grazing animals as a result of intensification. The lack of a decline in soil $\mathrm{pH}$ may have been related to the declining soil organic matter level lowering hydrogen ion-supplying power. The lower-than-expected responsiveness of Olsen P to fertiliser P application was probably because the experimental area had a very poor fertiliser application history, in comparison with previous experiments against which Olsen $\mathrm{P}$ was calibrated.
\end{abstract}

Keywords: carbon, fertiliser application, hill country, Olsen $\mathrm{P}$, organic matter, $\mathrm{pH}$, soils

\section{Introduction}

Following clearance of forested southern North Island hills in the late $19^{\text {th }}$ and early $20^{\text {th }}$ centuries, farming practices that increased pasture and animal production, while minimising reversion to scrub, were developed (Levy 1951). Available nitrogen (N), phosphorus (P) and sulphur (S) were the most common deficiencies for pasture growth, and the last two were alleviated principally by application of single-superphosphate. Access to aerial-application technology in the early 1950s made feasible large-scale spreading of superphosphate, resulting in enhanced legume growth and $\mathrm{N}$ fixation, greater pasture production, and intensification of grazing systems.

In a grazing experiment started in 1975 in southern North Island hill country, we measured effects of longterm fertiliser treatments on soils, pastures and animals (Lambert et al. 1983, 1986; Clark 1986; Mackay et al. 1995). In this paper we consider changes in three soil characteristics (organic carbon content, $\mathrm{pH}$ and Olsen $\mathrm{P}$ status) over time. It has been commonly assumed that pasture improvement has a positive influence on soil quality, by increasing organic matter (soil $\mathrm{C} \times 1.7$ ) content of the soil (Haynes \& Williams 1993). Intensification of pastoral agriculture has been reported to depress soil $\mathrm{pH}$ (Bolan et al. 1991), which is seen as a negative effect. Olsen $P$ status is widely employed as a measure of level of plant-available $\mathrm{P}$, and so its change in time in response to application of fertiliser $\mathrm{P}$ is of major interest to farmers and technical advisors.

\section{Methods}

An area of low-fertility hill country (sedimentary yellowbrown earths and intergrades to yellow-grey earths, and related steepland soils; average annual rainfall 1270 $\mathrm{mm}$ ) at AgResearch's Ballantrae Research Station was divided into 10 farmlets of 7-14 ha each. The whole area received $250 \mathrm{~kg} / \mathrm{ha} / \mathrm{yr}$ superphosphate in 1973 and 1974. Subsequently, half the farmlets (LF) received an average $125 \mathrm{~kg} / \mathrm{ha}$ superphosphate, while the other half (HF) received annual capital dressings averaging 625 $\mathrm{kg} /$ ha for 5 years, then $375 \mathrm{~kg} / \mathrm{ha}$ annually (Table 1). Lime was also applied to HF in 1975 and 1979. Stock were predominantly sheep, although cattle were also grazed at various times during the experiment. Stocking rate (Table 1) was increased in line with increases in pasture production.

Soil samples (0-75 $\mathrm{mm}$ depth) were taken annually in winter, before spring application of fertiliser. Samples were taken from 3 slope $\times 3$ aspect strata within farmlets (Lambert et al. 1983), and bulked across aspects before 
Table 1 Fertiliser treatment (kg applied/ha) and stocking rate (ewe equivalents/ha) details.

\begin{tabular}{|c|c|c|c|c|c|c|c|c|c|c|c|c|c|c|}
\hline & 1973 & 1974 & $1975^{a}$ & 1976 & 1977 & 1978 & $1979^{b}$ & 1980 & 1981 & 1982 & 1983 & 1984 & 1985 & 1986 \\
\hline \multicolumn{15}{|c|}{ Superphosphate application } \\
\hline LF & 250 & 250 & 250 & 0 & 125 & 125 & 125 & 125 & 125 & 125 & 125 & 125 & 125 & 125 \\
\hline $\mathrm{HF}$ & 250 & 250 & 750 & 500 & 875 & 500 & 500 & 375 & 375 & 375 & 375 & 375 & 375 & 375 \\
\hline \multicolumn{15}{|c|}{ Stocking rate } \\
\hline LF & 6.0 & 6.0 & 6.5 & 10.5 & 9.3 & 8.7 & 9.9 & 10.9 & 12.0 & 12.0 & 12.0 & 12.0 & 12.0 & 12.0 \\
\hline $\mathrm{HF}$ & 6.0 & 6.0 & 8.8 & 11.4 & 11.6 & 11.8 & 13.3 & 14.6 & 16.1 & 16.1 & 16.1 & 16.1 & 17.2 & 17.2 \\
\hline
\end{tabular}

a Limestone applied at $1250 \mathrm{~kg} / \mathrm{ha}$ to all $\mathrm{HF}$ farmlets

${ }^{\text {b }}$ Limestone applied at $2500 \mathrm{~kg} / \mathrm{ha}$ to all HF farmlets

analysis. Samples were air-dried, ground and stored, before laboratory analysis in one run (apart from those for 1987 which were analysed separately). Results were averaged across slopes within farmlet, and across farmlets within fertiliser level. Organic $\mathrm{C}$ concentrations were converted to contents to $75 \mathrm{~mm}$ depth, using measured soil bulk density. Anion storage capacity was low $(26 \%)$.

\section{Results and Discussion}

\section{Organic carbon}

Organic $\mathrm{C}$ content declined throughout the measurement period, in both LF and HF treatments. The rate of decline was similar $(\mathrm{P}>0.05)$ (Figure 1), on average $206\left(\mathrm{R}^{2}=\right.$ $0.53, \mathrm{P}<0.01)$ and $186\left(\mathrm{R}^{2}=0.47, \mathrm{P}<0.01\right) \mathrm{kg} / \mathrm{ha} /$ year during $1975-87$ for LF and HF respectively. This was contrary to the expectation that increasing fertiliser inputs and stocking rates would build up organic matter content.
The net annual loss of about $200 \mathrm{~kg} \mathrm{C} /$ ha must have been a result of losses exceeding inputs. The fertiliser treatments increased annual net herbage accumulation rates, for example by an average $27 \%$ (LF) and $70 \%$ (HF) above pre-trial levels during 1975/76 to 1980/81. We estimate this would have increased annual inputs of $\mathrm{C}$ to the soil pool from plant litter and grazing animal faeces by 400 and $1400 \mathrm{~kg} / \mathrm{ha}$, respectively. This suggests that although the net soil C losses from LF and HF soils were similar, the total loss from the HF soils was greater by about $1000 \mathrm{~kg} \mathrm{C} / \mathrm{ha} /$ year, and countered the greater inputs.

Reasons for accelerated losses in soil C (i.e, during the trial compared with pre-trial levels, and also the higher total loss under HF cf LF) most likely include greater activity of soil decomposers because of alleviation of $\mathrm{P}, \mathrm{S}$, and $\mathrm{N}$ limitations, and more rapid incorporation of surface litter into the soil through greater earthworm (Lambert 1986) and hoof action. Also, relative $\mathrm{C}$ partitioning to roots decreased (Saggar et al.

Figure 1 Soil organic carbon contents for low and high fertiliser treatments during 1972-1987.

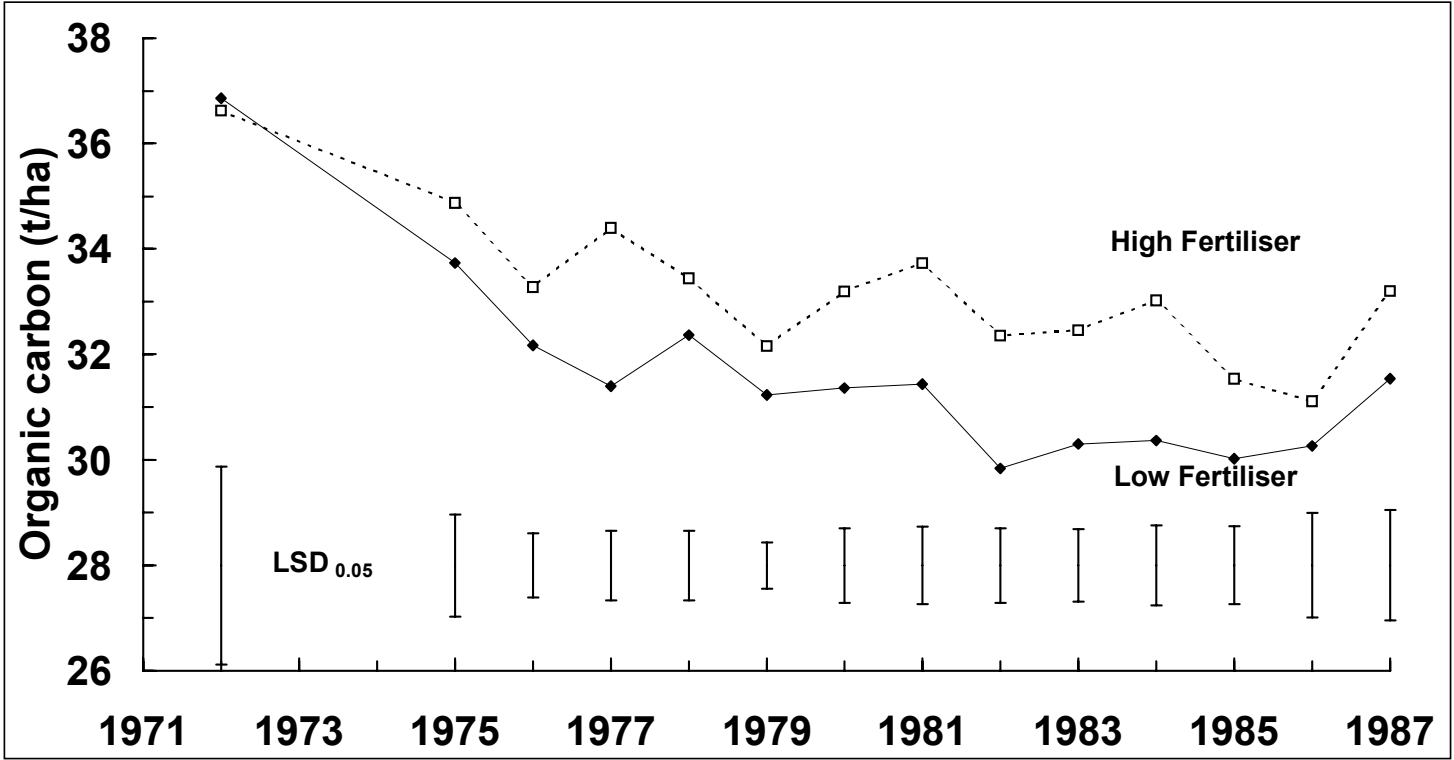


1997), and utilisation of herbage grown was greater with intensification, leading to a greater proportion of $\mathrm{C}$ fixed by plants being ingested by grazing animals and lost to the atmosphere as $\mathrm{CO}_{2}$ and $\mathrm{CH}_{4}$ during rumen fermentation and respiration.

The mostly commonly cited references demonstrating organic matter accumulation during pasture improvement are those of Walker et al. (1959) and Jackman (1964). In most instances the soils sampled in those chronosequence studies had been cultivated, hence mixing low $\mathrm{C}$ subsoil with higher $\mathrm{C}$ topsoil, and in some cases soil $\mathrm{C}$ had been depleted by cropping. This is in contrast to our study, where soils had been under permanent pasture for decades before intensification. The measured depletion in soil C does not necessarily mean nutrient-supplying power was decreased. On the contrary, content of total $\mathrm{N}$ increased in the HF soils, and content of total $\mathrm{P}$ and organic $\mathrm{S}$ increased in both $\mathrm{HF}$ and LF soils. However, the loss of $\mathrm{C}$ does give cause for concern, in terms of potential long-term influences on soil physical structure and watersupplying capacity, and also because of the undesirability of increased emission of greenhouse gases.

\section{Soil pH}

Soil $\mathrm{pH}$ increased slowly in the LF treatment during the experiment (Figure 2). Lime application to the HF area, after the 1975 and 1979 soil samplings, boosted $\mathrm{pH}$ by 0.23 and 0.29 units, respectively. This was followed by a decline in $\mathrm{pH}$, commencing in the second or third year after lime application and in line with general expectations, although the difference was still 0.14 units in 1987.

It has been proposed that soil acidification occurs in legume-based pasture soils as a result of fixation of $\mathrm{N}$ by legumes, leaching of $\mathrm{NO}_{3}-\mathrm{N}$, soil $\mathrm{N}$ transformations, and increases in organic matter content (Bolan et al. 1991). Annual N fixation rates were greater with intensification in this study (Lambert 1987), although $\mathrm{N}$ leaching losses were very low (Sakadevan et al. 1993). The absence of a decline in $\mathrm{pH}$ in the LF soils is probably related to the decline in soil organic matter and hence lowered potential to generate hydrogen ions.

\section{Olsen P status}

Olsen P increased initially, then declined and remained at a constant level of 7-8 for 1977-87 in the LF treatment. In the HF treatment it increased throughout the measurement period (Figure 3).

The initial rise in the LF Olsen $\mathrm{P}$ value was a result of three annual dressings of $250 \mathrm{~kg}$ superphosphate/ha. This was followed by a year of no fertiliser application and a resultant fall in Olsen $P$, then repeated annual dressings of $125 \mathrm{~kg} / \mathrm{ha}(12 \mathrm{~kg} \mathrm{P} / \mathrm{ha})$ and relatively constant Olsen P during 1979-87. This suggests $12 \mathrm{~kg}$ $\mathrm{P} /$ ha was the "maintenance" rate at the prevailing stocking rate (11.4 su/ha), i.e., about $1.1 \mathrm{~kg} \mathrm{P} / \mathrm{su}$, which is in line with industry recommendations (Morton et al. 1994).

For the HF soils, Olsen P reflected superphosphate application rate reasonably well, although there were unexplainable year to year variations - this emphasises the advantages of sampling regularly (annually

Figure 2 Soil pH values for low and high fertiliser treatments during 1972-1987.

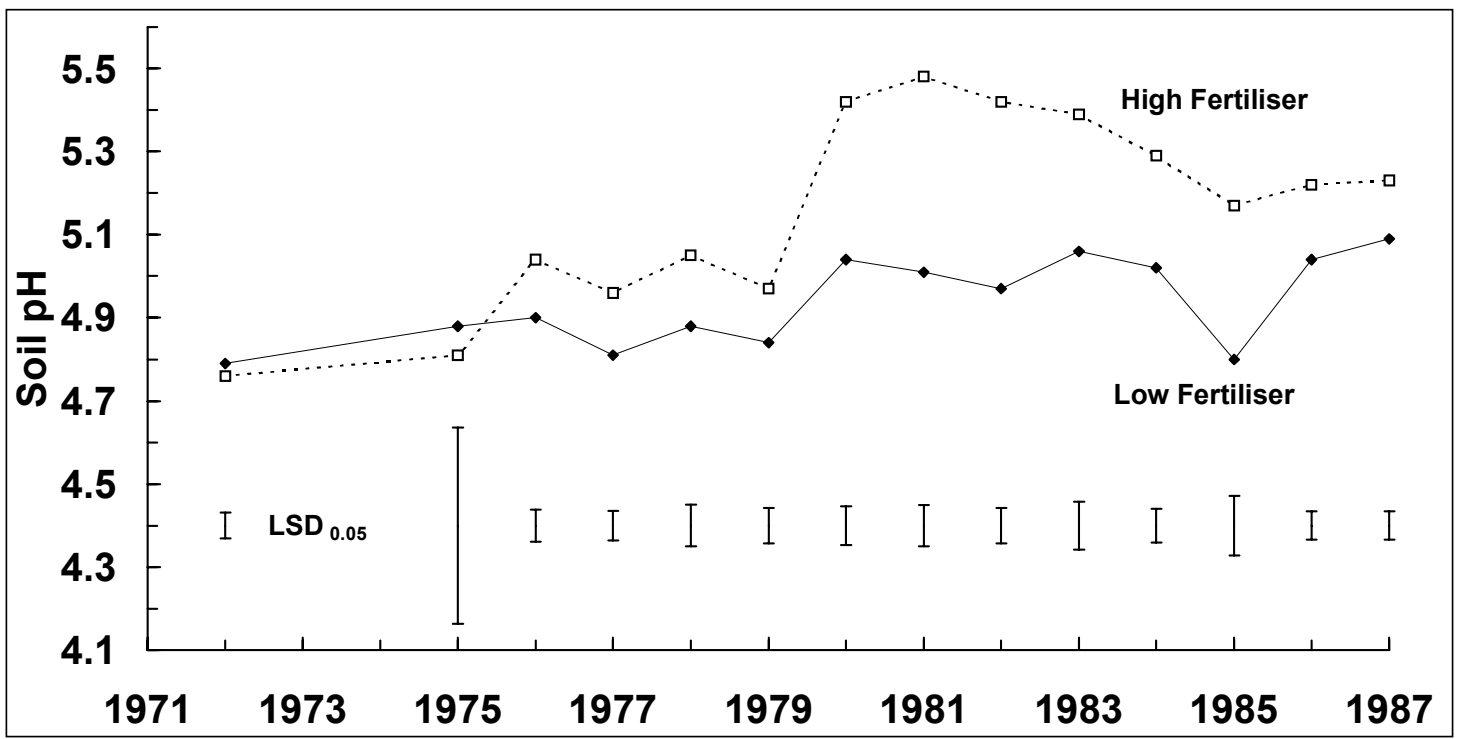


Figure 3 Soil Olsen P levels for low and high fertiliser treatments during 1972-1987.

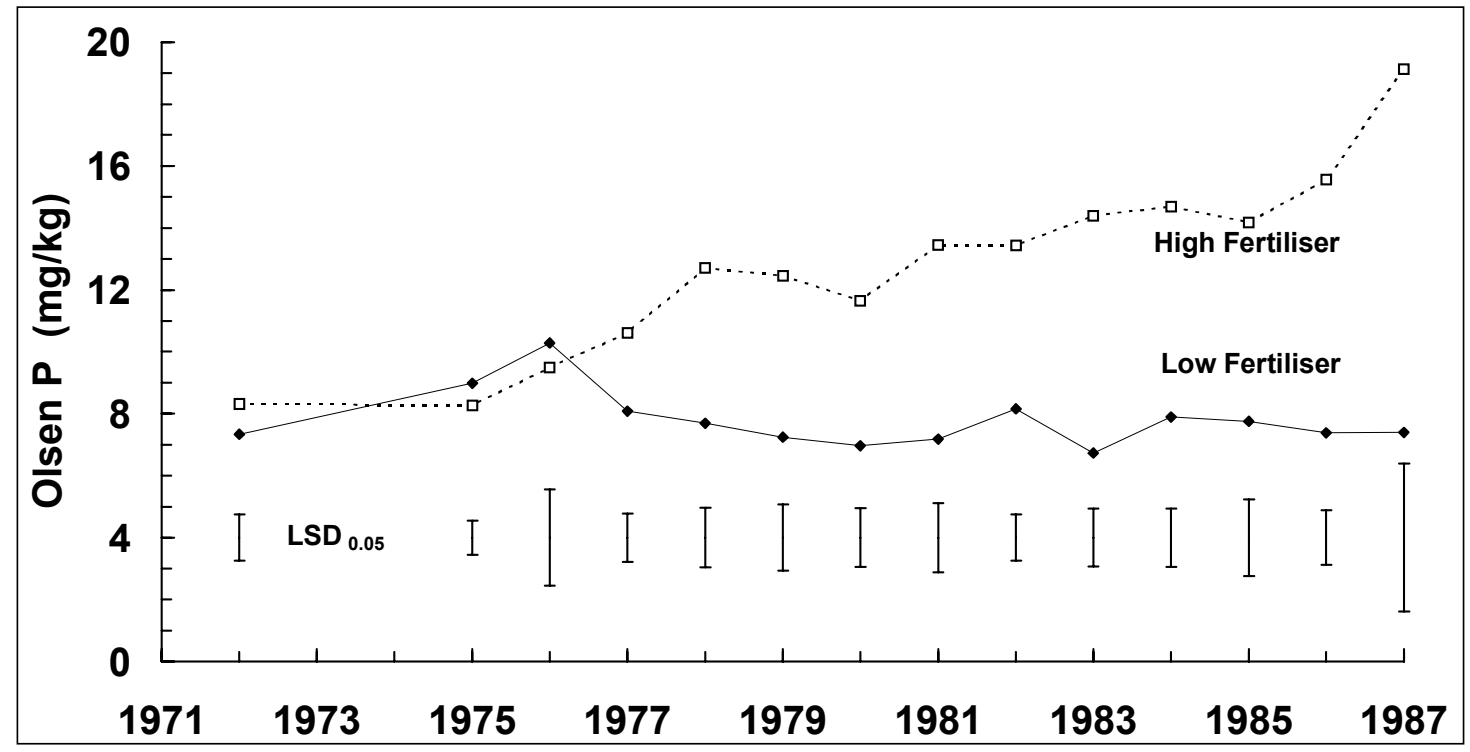

preferably) to establish a trend in Olsen P status, rather than relying on comparisons between individual years (e.g., before and after a capital dressing) as a measure of changing status. The sensitivity of the Olsen $P$ value to superphosphate application was much lower than expected. For the HF treatment, fertiliser $\mathrm{P}$ applied above maintenance requirements averaged $16 \mathrm{~kg} / \mathrm{ha}$ annually during 1981-87 (earlier years were excluded as lime application depresses Olsen P values; Lambert \& Grant 1980), and for that period approximately $13 \mathrm{~kg}$ $\mathrm{P}$ was required to raise Olsen $\mathrm{P}$ by 1 unit. This compares with the $4-7 \mathrm{~kg} / \mathrm{ha} P$ reported to be required to move Olsen $P$ by 1 unit on sedimentary soils under sheep and beef systems (Morton et al. 1994). This discrepancy may have arisen because the present experiment was conducted during "pasture improvement" from a lowfertility background, whereas the guideline of Morton et al. (1994) may be more applicable to soils with an extensive fertiliser application history. The Olsen reagent extracts $\mathrm{P}$ from organic and inorganic pools, the organic contribution being from micro-organisms killed during air-drying of soil before analysis and varying across soils (Sparling et al. 1985). Presumably this could also be the case across levels of development within the same soil, and this could lead to changing sensitivity of the test to fertiliser application. There was a suggestion in the 1996 and 1997 values that responsiveness of the test was increasing, and this is borne out in data collected subsequently.

This recorded low level of sensitivity at low fertility should be of value to extension staff who have been castigated by farmers when recommended capital dressings of phosphatic fertiliser do not greatly elevate Olsen P values. It should also be remembered that soil tests are not the ultimate diagnostic tool - they should be used as part of a package, in conjunction with other measures such as plant tissue testing, assessment of pasture botanical composition and productivity, and animal performance levels.

\section{ACKNOWLEDGEMENTS}

Andrew Carran provided much useful discussion which contributed to our interpretation of the data sets.

\section{REFERENCES}

Bolan, N.S.; Hedley, M.J.; White, R.E. 1991. Processes of soil acidification during nitrogen cycling with emphasis on legume based pastures. Plant and soil 134: 53-64.

Clark, D.A.; Lambert, M.G.; Grant, D.A. 1986. Influence of fertiliser and grazing management on North Island moist hill country 5. Animal production. New Zealand journal of agricultural research 29: 407420.

Haynes, R.J.; Williams, P.H. 1993. Nutrient cycling and soil fertility in the grazed pasture ecosystem. Advances in agronomy 49: 119-199.

Jackman, R.H. 1964. Accumulation of organic matter in some New Zealand soils under permanent pasture. 1. Patterns of change of organic carbon, nitrogen, 
sulphur and phosphorus. New Zealand journal of agricultural research 7: 445-471.

Lambert, M.G. 1986. Earthworms in southern North Island hill pasture. Proceedings of the New Zealand Grassland Association 47: 279-282.

Lambert, M.G. 1987. Nitrogen fixation during improvement of North Island hill country pastures. New Zealand journal of experimental agriculture 15: 267-270.

Lambert, M.G.; Grant, D.A. 1980. Fertiliser and lime effects on some southern North Island hill pastures. New Zealand journal of experimental agriculture 8: 223-229.

Lambert, M.G.; Clark, D.A.; Grant, D.A.; Costall, D.A.; Fletcher, R.W. 1983. Influence of fertiliser and grazing management on North Island hill country. 1. Herbage accumulation. New Zealand journal of agricultural research 26: 95-108.

Lambert, M.G.; Clark, D.A.; Grant, D.A.; Costall, D.A. 1986. Influence of fertiliser and grazing management on North Island hill country. 2. Pasture botanical composition. New Zealand journal of agricultural research 29: 1-10.

Levy, E.B. 1951. Grasslands of New Zealand. Wellington, Government Printer.

Mackay, A.D.; Lambert, M.G.; Trolove, S.N.; Costall, D.A. 1995. Effect of long-term fertiliser use and sheep grazing on the accumulation and distribution of nitrogen, phosphorus and sulphur in a hill soil. pp. 206-219. In: Proceedings of the Massey University Workshop: Fertiliser requirements of grazed pasture and field crops.

Morton, J.D.; Roberts, A.C.H.; Edmeades, D.C. 1994. Fertiliser use on sheep and beef farms. AgResearch.

Saggar, S.; Hedley, C.; Mackay, A.D. 1997. Partitioning and translocation of photosynthetically fixed ${ }^{14} \mathrm{C}$ in grazed hill pastures. Biology and fertility of soils 25: 152-158.

Sakadevan, K.; Mackay, A.D.; Hedley, M.J. 1993. Influence of sheep excreta on pasture uptake and leaching losses of sulfur, nitrogen and potassium from grazed pastures. Australian journal of soil research 31: 151-162.

Sparling, G.P.; Whale, K.N.; Ramsay, A.J. 1985. Quantifying the contribution from the soil microbial biomass to the extractable P levels of fresh and airdried soils. Australian Journal of soil research 23: 613-621.

Walker, T.W.; Thapa, B.K.; Adams, A.F.R. 1959. Studies on soil organic matter: 3. Accumulation of carbon, nitrogen, sulphur, organic and total phosphorus in improved grassland soils. Soil science 87: 135-140. 